\title{
Heat-stress increase under climate change twice as large in cities as in rural areas: a study for a densely populated mid-latitude maritime region
}

\author{
Hendrik Wouters ${ }^{1,5}$, Koen De Ridder ${ }^{2}$, Lien Poelmans ${ }^{2}$, Patrick Willems ${ }^{3}$, Johan Brouwers ${ }^{4}$, \\ Parisa Hosseinzadehtalaei $^{3}$, Hossein Tabari ${ }^{3}$, Sam Vanden Broucke ${ }^{1}$, Nicole P.M. van \\ Lipzig $^{1}$, Matthias Demuzere ${ }^{1,5}$ \\ ${ }^{1}$ KU Leuven, Dept. Earth and Environmental Sciences, Celestijnenlaan 200E, B-3001 Heverlee, Belgium \\ ${ }^{2}$ Flemish Institute for Technological Research, Environmental Modelling Unit, Boeretang 200, B-2400 Mol, Belgium \\ ${ }^{3}$ KU Leuven, Dept. of Civil Engineering, Kasteelpark Arenberg 40, box 2448, B-3001 Heverlee, Belgium \\ ${ }^{4}$ Flanders Environment Agency, Dokter De Moorstraat 24-26, B-9300 Aalst, Belgium \\ ${ }^{5}$ Laboratory of Hydrology and Water Management, Ghent University, B-9000 Ghent, Belgium
}

\section{Key Points:}

- Urban climate ensemble projections with unprecedented detail demonstrate a heatstress increase twice as large for cities as for rural areas.

- Urban heat stress by the mid- $21^{\text {st }}$ century is multiplied by a factor 1.4 to 15 , depending on the emission and land-use scenario

- The urban hot spots of global warming are established by the urban heat islands, their concurrence with heatwaves, and urban expansion. 


\begin{abstract}
Urban areas are usually warmer than their surrounding natural areas, an effect known as the urban heat island effect. As such, they are particularly vulnerable to global warming and associated increases in extreme temperatures. Yet ensemble climate-model projections are generally performed on a scale that is too coarse to represent the evolution of temperatures in cities. Here, for the first time, we combine unprecedented long-term (35-year) urban-climate model integrations at the convection-permitting scale $(2.8 \mathrm{~km}$ resolution) with information from an ensemble of general circulation models to assess temperature-based heat stress for Belgium, a densely populated mid-latitude maritime region. We discover that the heat-stress increase towards the mid- $21^{\text {st }}$ century is twice as large in cities compared to their surrounding rural areas. The exacerbation is driven by the urban heat island itself, its concurrence with heatwaves, and urban expansion. Cities experience a heat-stress multiplication by a factor 1.4 and 15 depending on the scenario. Remarkably, the future heat-stress surpasses everywhere the urban hot spots of today. Our results demonstrate the need to combine information from climate models, acting on different scales, for climate-change risk assessment in heterogeneous regions. Moreover, these results highlight the necessity for adaptation to increasing heat stress, especially in urban areas.
\end{abstract}

\title{
1 Introduction
}

Expanding urban areas are hot spots that drive environmental change at multiple scales around the globe [Seto et al., 2012; Grimm et al., 2008]. Particularly, greenhouse gas emissions and land-use changes both lead to global warming and shifts in weather extremes [Kalnay and Cai, 2003; Revi et al., 2014] with more intense, more frequent and longer lasting heatwaves [Meehl and Tebaldi, 2004]. The climatic changes are expected to adversely influence the economy, eco-systems and humans that are exposed to it [Watts et al., 2015; Revi et al., 2014; Seto et al., 2012]. Heatwaves particularly result in excessive mortality rates [Mora et al., 2017; Mazdiyasni et al., 2017; Mitchell et al., 2016; Green et al., 2016; Cox et al., 2016; Xu et al., 2016; Tong et al., 2015; Huang et al., 2012], higher hospital admissions [Linares et al., 2017; Iñiguez et al., 2016; Díaz et al., 2015], preterm delivery [Cox et al., 2016], economic and labour productivity loss [Estrada et al., 2017; Zander et al., 2015], damage to infrastructure and higher energy usage [Revi et al., 2014]. The total death toll by extreme temperatures hitting Europe in Summer 2003 and the Russian Federation in Summer 2010 make heatwaves the second deadliest kind of disaster related to weather extremes during the period 2001 to 2010 [WMO, 2014]. The cities - housing already more than $50 \%$ of the global population [United Nations, 2014] - experience an excessive death toll during heatwaves compared to the natural surroundings because of the urban heat island (UHI) effect [Heaviside et al., 2016; Hoag, 2015; Watts et al., 2015; Laaidi et al., 2011; Gabriel and Endlicher, 2011; Kalnay and Cai, 2003] and also a excessive economic loss [Estrada et al., 2017].

Recent studies have been using ensemble general circulation models (GCMs) and regional climate models (RCMs) to address the future (heatwave-related) risks of climate change around the globe including the role of urbanization [Mora et al., 2017; Estrada et al., 2017; Mitchell et al., 2016; Fischer et al., 2012; Taylor et al., 2012; Diffenbaugh and Giorgi, 2012; Fischer and Schär, 2010; Wilby, 2008; Meehl and Tebaldi, 2004]. However, all of these studies use climate information on a scale ( coarse to resolve the inter-urban variability of the cities. In order to capture the associated heterogeneity in urban-atmospheric feedbacks, the local circulations and weather conditions, one requires to resolve at least the scale of the cities themselves $\left(<100 \mathrm{~km}^{2}\right)$. The latter is particularly a prerequisite to distinguish between the cities with different urban characteristics, including the imperviousness (abundance of buildings, streets, parkings and other manmade water-impermeable pavements) and other local environmental aspects (distance from the coastline, soil texture, orography...). It is also indispensable for taking the local land-use change such as urban expansion into account. Convection-permitting models (CPMs; size of 
grid cells $\leq 25 \mathrm{~km}^{2}$ ), offering more than 100 times more grid cells per unit area than those previous assessments, are able to explicitly resolve the local heterogeneous weather conditions and especially the urban heat island effect [eg., Trusilova et al., 2016; Jänicke et al., 2016; Wouters et al., 2016, 2013; Bohnenstengel et al., 2011; Van Weverberg et al., 2008]. As such, they allow to identify the local hot spots and the associated urban climate-change risks [Prein et al., 2015]. Yet, CPM downscaling is computationally very expensive, hence recent studies [eg., Fosser et al., 2017; Argüeso et al., 2015] only consider a limited amount of emission and land-use scenarios [Kendon et al., 2017]. As such, they do not provide the statistically robust information and uncertainty regarding the ensemble climate-change statistics in weather extremes such as heatwaves.

Here, we project temperature-based urban heat-stress under global warming with a unique combination of CPM urban climate downscaling [Wouters et al., 2016; Rockel et al., 2008], ensemble information from GCMs [Taylor et al., 2012; Willems and Vrac, 2011], and socio-demographic land-use change modelling [White and Engelen, 2000]. The CPM climate simulations are performed covering continuous periods of 35 years over an extended heterogeneous urban area. As such, heat stress is quantified for a historical (1980-2014) and a future (2040-2074) period with different global emission scenarios and local land-use scenarios for Belgium, one of the most densely populated and urbanized regions in Europe [The World Bank, 2017]. The Belgian scene comprises a compelling case for a mid-latitude maritime climate regime with cities of multiple sizes and urban sprawl throughout the domain. It also includes a topographical scene with flatlands in the North, a coastal area in the West, and a hilly area in the South, see Figure S1. In order to account for the temperature changes and associated uncertainties occurring at the global and local scale, a set of global emission scenarios and local land-use change scenarios are considered. A description of the urbanclimate downscaling, the heat-stress indicator, the greenhouse-gas emission and land-use change scenarios and the decomposition of the climatic drivers of urban heat-stress increase is given in the 'methods' section. The results and discussion are presented in Sections 3 and 4, respectively. Finally, the implications for policy are provided in Section 5.

\section{Materials and methods}

\subsection{CPM climate downscaling}

A control experiment for heat-stress assessment is obtained from a 35-year (19802014) CPM urban-climate hindcast simulation with the COSMO-CLM model [Rockel et al., 2008; Doms et al., 2011; Buzzi, 2008; Smiatek et al., 2008; Steppeler et al., 2003] coupled to the urban land-surface scheme TERRA_URB [Wouters et al., 2015, 2016; Demuzere et al., 2017] configured over Belgium at $2.8 \mathrm{~km}$ resolution (Figure S1). The downscaling strategy takes the lateral boundary conditions from the ERA-INTERIM-driven COSMO-CLM simulation at $12.5 \mathrm{~km}$ resolution from the COordinated Regional climate Downscaling EXperiment (CORDEX) for Europe [Kotlarski et al., 2014; Jacob et al., 2013; Vautard et al., 2013]. In agreement to the evaluation of the climate model in earlier studies [Brisson et al., 2016a,b; Wouters et al., 2015, 2016; Trusilova et al., 2016; Demuzere et al., 2017; Davin et al., 2016], the control simulation was found to reproduce both the observed coarse temperature climatology and the urban-heat islands of the study domain very well, see Figures S2, S3 and S4 and Table S4. A detailed description and evaluation of the urban climate model and its control configuration is provided in the Supporting Information (see Texts S1 to S4) [WMO, 2008; Davin et al., 2016; Davy and Esau, 2014; Jacob et al., 2007; Wouters et al., 2013; Dimitrova et al., 2016; Thiery et al., 2016; Vanden Broucke et al., 2015; Akkermans et al., 2014; Davin et al., 2014; Grossman-Clarke et al., 2016; Prein et al., 2013; Grasselt, 2008; Schulz et al., 2016; Haylock et al., 2008; De Ridder et al., 2015].

Even though the model has a very good skill in accordance to previous (CPM) model evaluations, the threshold-based heat-stress indicator is very sensitive to the model bias. Therefore, a bias correction is applied according to gridded daily temperature fields and ur- 
ban climate observations. Details about the bias correction can be found in Text S5. As such, the modelled record of the heat-stress indicator matches very well the urban-climate observations in Antwerp, especially the urban/rural contrast (see Figure S5).

\subsection{Heat-stress indicator}

In order to quantify heat stress for Belgium under climate change, the heat-stress indicator from the Flanders Environment Agency is applied. It has been developed in cooperation with several research institutes and governmental agencies regarding climate, care and health in Belgium. It is used to monitor the potential effect of heat stress episodes on a yearly basis, as a part of the state of the environment reporting in Flanders [Brouwers et al., 2015], see http://www . milieurapport. be. The heat-stress indicator is obtained by the summing over the days $(i)$ from the beginning of April until the end of September:

$$
\sum_{i}\left[\left(T_{\min , i}-18.2^{\circ} \mathrm{C}\right)^{+}+\left(T_{\max , i}-29.6^{\circ} \mathrm{C}\right)^{+}\right] h_{i}
$$

On the one hand, the frequency and length of heatwaves are considered by means of $h_{i}$, which indicates the occurrence of a heatwave day when heatwave alarm levels for temperature are exceeded: It equals to one in case the daily minimum $\left(T_{\min , i}\right)$ and maximum $\left(T_{\max , i}\right)$ temperature simultaneously exceed their respective thresholds $18.2^{\circ} \mathrm{C}$ and $29.6{ }^{\circ} \mathrm{C}$ during three consecutive days, whereas it equals to zero for the other days. On the other hand, the intensity of the heatwaves is taken into account with the concept of exceeding values of those temperature thresholds. Therefore, the terms in the inner brackets $(\ldots)^{+}$represent the exceedance of $T_{\min , i}$ and $T_{\max , i}$ above their respective threshold values $18.2{ }^{\circ} \mathrm{C}$ and $29.6{ }^{\circ} \mathrm{C}$. A motivation of the used heat-stress indicator is provided by Text S6.

\subsection{Local land-use change scenarios}

Two static local land-use scenarios are considered for the CPM climate integrations, namely a historical urbanization (LND:HST; reference year 2000) and a future business-asusual urbanization (LND:BAU; reference year 2060) [Acosta-Michlik et al., 2011]. They are created using the cellular automata modelling approach [White and Engelen, 2000], starting from CORINE land-cover dataset for the reference year 2000 on a $300 \mathrm{~m}$ resolution. The model takes into account the land-use changes from the past, while societal boundary conditions with regard to future policy include economic and demographic changes at the different governmental levels. Based on the behavior of pattern changes of land-use from the past, a business-as-usual-scenario is obtained. By making an overlay with the existing impervious surface area (abundance of buildings, streets, parkings and other man-made waterimpermeable pavements) from Maucha et al. [2010], the land-use maps are used for estimating the impervious surface area for the historical and future urbanization, which in turn is taken as input for the CPM climate downscaling. Detailed information can be found in Text S3 (see also Figure S6).

\subsection{Global emission scenarios}

Global emission scenarios are constructed according to the delta-change approach [Tabari et al., 2015; Willems and Vrac, 2011]. It considers the absolute changes between the temperature distributions from future ensemble scenario runs and those from present-day control runs. Similar as in previous assessment studies [eg., Ahlström et al., 2012], these are added to the historical timeseries to obtain the future temperatures. The changes in the 10category quantiles of the distributions for each month separately of the daily minimum and maximum temperature between the periods 1961-1990 and 2071-2100 are extracted from ensemble GCM data. The changes are rescaled to obtain the results between the periods 19802014 and 2040-2074. The ensemble data includes 42 simulations comprising 11 control runs and 31 future scenario runs $(8 \times \mathrm{RCP} 2.6$; $8 \times \mathrm{RCP} 4.5$; $6 \times \mathrm{RCP} 6.0$; and $9 \times \mathrm{RCP} 8.5$; full member list provided in Table S3). These are provided by 11 GCMs from the Coupled 
Model Intercomparison Project of the World Climate Research Programme Phase 5 (CMIP5) multi-model experiment [Taylor et al., 2012; Moss et al., 2008]. Three scenarios are constructed from this ensemble, namely the best-case (EMI:BEC), the median (EMI:MED) and the worst-case (EMI:WOC) scenario. They respectively consider the $5^{\text {th }}, 50^{\text {th }}$ and $95^{\text {th }}$ percentile values of the above-mentioned changes, offering the uncertainty range of future temperature changes (see Figure S7, panels A and B). The percentile changes are applied to the historical CPM downscaling fields described in Section 2.1.

A motivation and interpretation of the global emission scenarios - especially their relation with the different RCP scenarios - are provided in the supporting Text S7 (see also Figure S7, panel C).

\subsection{Climatic drivers of heat-stress increase}

The total heat-stress increase under climate change expressed in heatwave degree days ( $\triangle$ HWDD; see Section 2.2) is decomposed [Stein and Alpert, 1993] into its different climatic drivers:

$$
\begin{aligned}
\Delta \mathrm{HWDD}_{\text {TOT AL }}= & \Delta \mathrm{HWDD}_{\mathrm{BASE}}+\Delta \mathrm{HWDD}_{\mathrm{SPD}}+ \\
& \Delta \mathrm{HWDD}_{\mathrm{CPM}} \_\mathrm{M}+\Delta \mathrm{HWDD}_{\mathrm{CPM} \_\mathrm{TD}}+ \\
& \Delta \mathrm{HWDD}_{\mathrm{CPM} \_L U C}+\Delta \mathrm{HWDD}_{\mathrm{SPD}, \mathrm{CPM}}
\end{aligned}
$$

The BASEline term (BASE) indicates the change according to the ensemble global emission scenarios (Section 2.4) by changing the monthly-mean temperatures of the coarse-scale record of gridded observations by Haylock et al. [2008] (see Figure S7, panel A). The Shifting Probability Distribution term (SPD) refers to the additional heat-stress increase when also taking into account the differential change in the monthly 10-category quantiles of the daily minimum and maximum temperature distributions (Section 2.4; see Figure S7, panel B). The contribution of urban heat-stress increase related to the CPM downscaling (Section 2.1) is quantified by subsequently adding the monthly-mean CPM (fine-scale) temperature deviation from the above coarse-scale observational record (CPM_MD), the inclusion of the day-to-day time-dependency of the CPM temperatures (CPM_TD), and the inclusion of the future local land-use change under a business-as-usual scenario (CPM_LUC; see Section 2.3). Finally, the additional covariance term (SPD,CPM) arises from simultaneously providing the information about the shifting probability distribution and the CPM downscaling.

\section{Results}

\subsection{Historical heat stress}

Results for the heat-stress indicator (Section 2.2) based on the present-day climate information (Section 2.1) from the CPM downscaling are presented below. Substantial temporal variation of annual-based historical heat stress is found (Figure S8): excessive heat stress is perceived for the heatwave years (1994, 1995, 2003, 2006, 2010, 2012 and 2013), whereas it vanishes for other years. For the years of extreme heat between 2001 to 2010, Belgium recorded an excessive heatwave-related mortality rate of 4200 people (http: //www. milieurapport. be). On the European scale, the death toll for the heatwave of 2003 have surpassed 70000 [Barriopedro et al., 2011]. A strong spatial variation of the heat stress is found as well. The city centers experience on average 17 heatwave degree days on an annual basis on average (see Figure 1), whereas peri-urban and rural areas only experience 12 and 2.6 days, respectively. As such, cities experience much higher heat stress than their respective natural surroundings, which is caused by the UHI effect. UHI intensities increase with city size (expressed in population number) and imperviousness [Zhou et al., 2013], hence the relation is also found for urban heat stress in the current results (compare Antwerp and Ghent in Figure S8). Inland cities experience larger heat stress than cities of comparable size closer to the coastline (compare Hasselt with Bruges in Figure S8). The hilly rural areas with the higher elevation levels in the South experience less heat stress compared to the lower rural flatlands in the North. Yet, the cities centers in the South still experience similar or even 


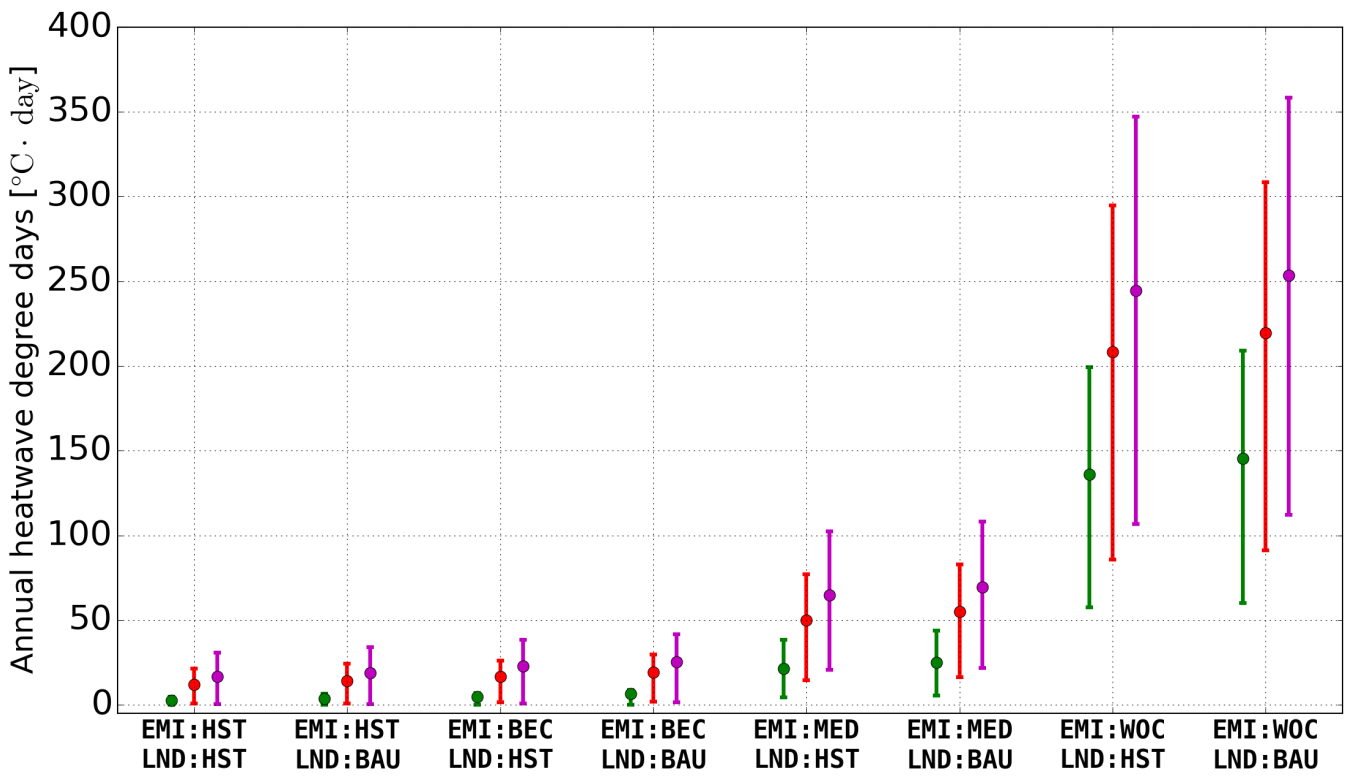

Figure 1. Climate downscaling hindcast (1980-2014) and projections (2040-2074) of heat stress for Belgium based on the ensemble emission scenarios (EMI:HiSTorical / EMI:BEst-Case / EMI:MEDian / EMI:WOrst-Case) and land-use change scenarios (LND:HiSTorical / LND:Business-As-Usual) for different urban classes. The results are averaged for different levels of impervious surface area fraction (ISA), ie. urban centers (purple; ISA for the surrounding $100 \mathrm{~km}^{2} \geq 50 \%$ ), peri-urban areas (red; $25 \% \leq \mathrm{ISA}\left(100 \mathrm{~km}^{2}\right.$ ) < $50 \%$ ) and rural areas (green; ISA $\left(100 \mathrm{~km}^{2}\right)<25 \%$ ). The bullets show the climatological mean, whereas the error bars show the climatological spread calculated from the range between the 5th and 95th percentile. An overview of the different scenarios are listed in Table S2, and their description (including the urban-climate downscaling methodology and the used heat-stress indicator) can be found in Section 2.

higher heat-stress as in the North, because they are located more inland and at low elevation levels in the river valleys (compare Liège with Ghent).

\subsection{Heat-stress projections}

On the basis of local land-use change scenarios described in Section 2.3 and global emission scenarios described in Section 2.4, future heat-stress projections are presented below. The role of the global emission scenarios is larger than the role of local land-use change scenarios in terms of the overall heat-stress increase under global warming and its spread for Belgium (Figures 1 and 2). On average, the heat stress in the urban centers is multiplied by a factor ranging from 1.5 and 15 depending on the emission scenario, considering the business-as-usual land-use change scenario. These increase factors become slightly smaller when the land-use change is not taken into account (between 1.4 and 14). Similar as for the historical heat-stress, the future heat-stress has a strong spatial variation. The hot spots are found in the urban centers experiencing an absolute increase of the annual heat stress from 6.0 to 237 heatwave degree days, and these hot spots become more intense away from the coastline. For the peri-urban areas and rural areas, the absolute increase is much smaller from 4.7 to 207 and from 2.2 and 143 heatwave degree days, respectively. As such, the absolute heat-stress increase is about twice as large for the city centers as for the natural surroundings (urban increment factor between 1.7 and 2.7 considering the different scenarios). The heat stress in the future climate in case of the median and worst-case emission scenarios 

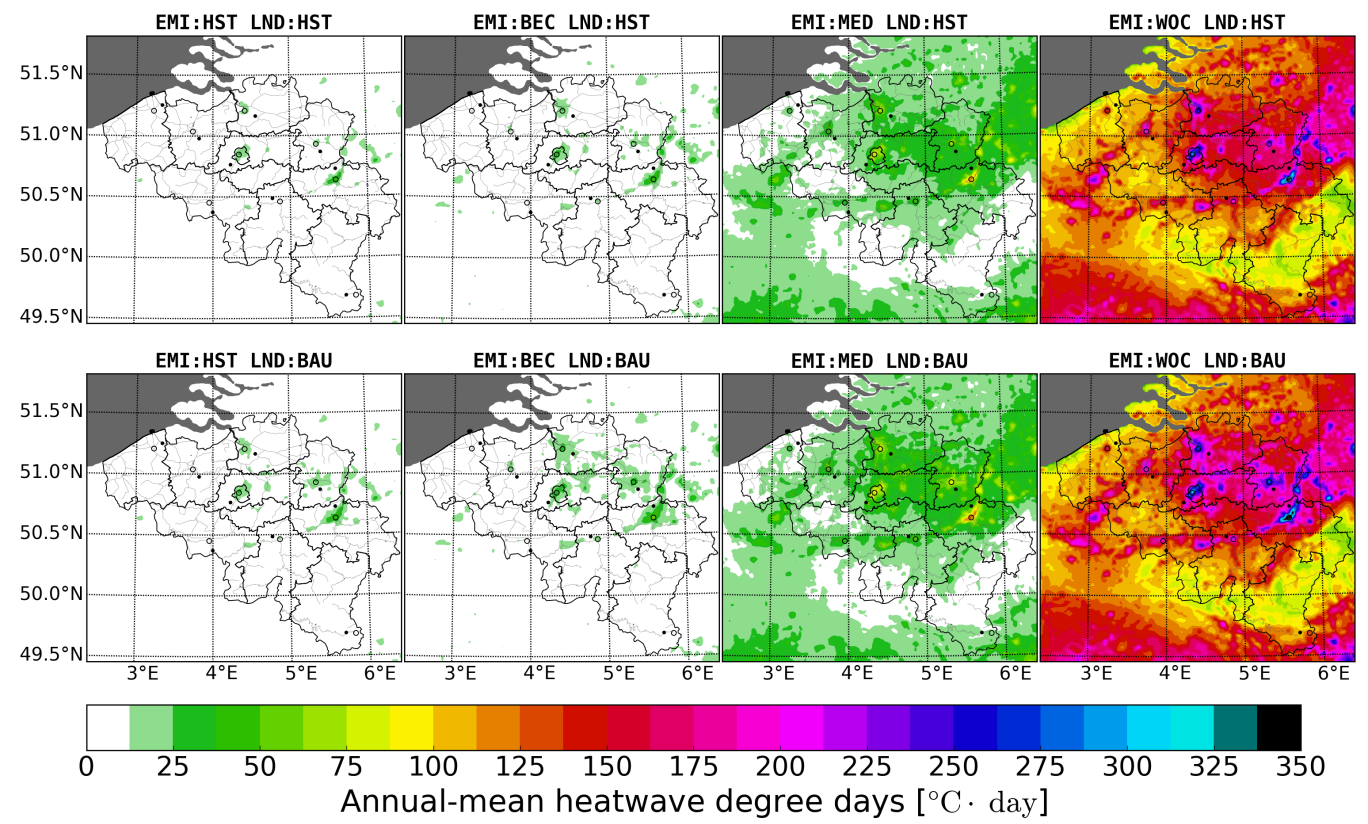

Figure 2. Climate downscaling hindcast (1980-2014) and projections (2040-2074) of annual-mean heat stress based on the global emission scenarios (EMI:HiSTorical / EMI:BEst-Case / EMI:MEDian / EMI:WOrst-Case) and local land-use change scenarios (LND:HiSTorical / LND:Business-As-Usual) over Belgium. The heat stress is expressed in heatwave degree days according to the heat-stress indicator provided in Section 2.2. An overview of the different scenarios are listed in Table S2, and their description can be found in Sections 2.3 and 2.4. The center of Brussels and the provincial capitals are indicated with circles. 

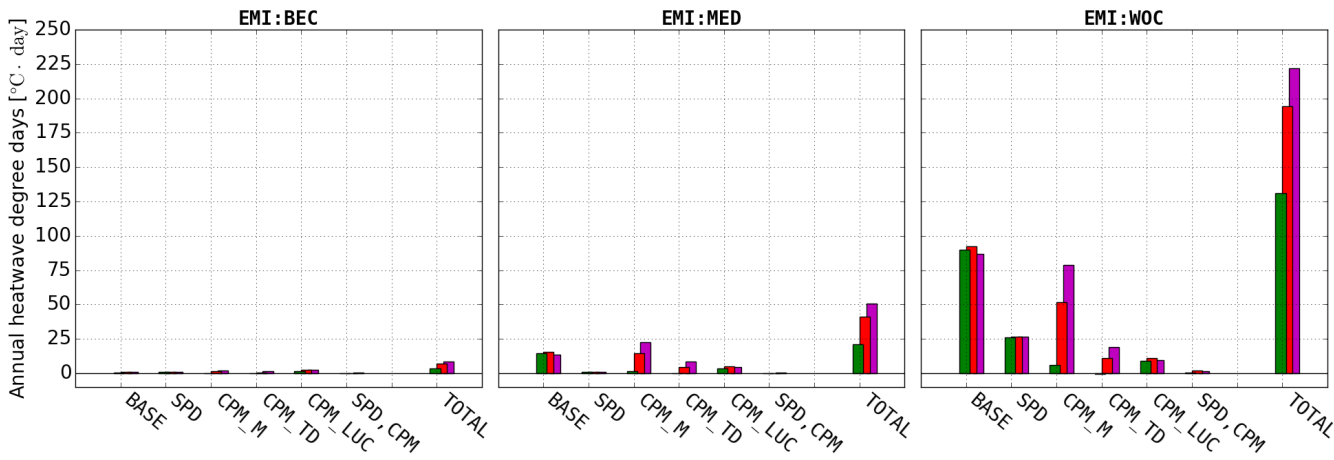

Figure 3. Total heat-stress increase (TOTAL) and its climatic drivers under the three global emission scenarios (EMI:HiSTorical / EMI:BEst-Case / EMI:MEDian / EMI:WOrst-Case), expressed in future change in annual heatwave degree days $\left[{ }^{\circ} \mathrm{C} \cdot\right.$ day]. Results are averaged for different levels of impervious surface area fractions, ie., urban centers (purple; Impervious Surface Area (ISA) for the surrounding $100 \mathrm{~km}^{2} \geq 50 \%$ ), peri-urban areas (red; $25 \% \leq \operatorname{ISA}\left(100 \mathrm{~km}^{2}\right)<50 \%$ ) and rural areas (green; ISA $\left(100 \mathrm{~km}^{2}\right)<25 \%$ ). The drivers consist of the baseline increase (BASE), the shifting probability distribution (SPD), the annual-mean contribution from the convection permitting model downscaling (CPM_M), its day-to-day time dependency (CPM_TD), the local land-use change (CPM_LUC) and finally the covariance between shifting probability distribution and the CPM downscaling information (SPD,CPM). Details about the emission scenarios and the decomposition of the climatic drivers can be found in the Sections 2.4 and 2.5 , respectively.

largely exceeds the heat stress during the extreme years (ie., the $95^{\text {th }}$ percentile value of the annual heat stress) in the current climate. In addition, the heat stress for the rural areas in the future climate is higher than for the cities in the current climate. Remarkably, the future heat stress for the worst-case emission scenario in the rural areas during the coldest years exceeds the present-day heat stress in the urban centers during the hottest years.

\subsection{Climatic drivers}

The presented scenarios allow for a decomposition of the different climatic drivers of heat-stress increase occurring at the different scales. The decomposition follows the methodology described in Section 2.5 and the results are shown in Figure 3. A substantial part of the heat-stress increase is explained by the global-warming trends in the GCMs imposed on coarse-scale gridded observational records. Herein, both the monthly-mean change (BASE) and the shifting probability distribution (SPD) of the daily temperatures are important. The latter stems from the shifting trends in high temperature extremes in the global emission scenarios, especially in the worst-case scenario (see Figure S7, panel B), for which an excessive increase of high extremes of daily temperatures is found with respect to the averaged temperatures increase. This is in agreement with the expected increase in temperature variance for Western Europe [Vogel et al., 2017; Horton et al., 2015; Donat and Alexander, 2012; Schär et al., 2004; Beniston et al., 2007; Seneviratne et al., 2006]. We reveal a profound exacerbation of heat-stress increase by the CPM climate downscaling. In the urban centers, the exacerbation ranges between $96 \%$ and $381 \%$ relative to the GCM-based trends depending on the emission scenario. Particularly, cities already experiencing higher temperatures due to the UHI effect perceive an additional heat-stress increase under global warming. We find that the major part of this excess is attributed to urban heat islands on a monthly basis (CPM_M). However, we demonstrate that the day-to-day variation of the CPM downscaling leads to an important additional excess as well (CPM_TD), and results from the excessive UHI intensities during heatwaves [Hamdi et al., 2016; Li and Bou-Zeid, 2013]. In fact, the high-pressure 
conditions with high surface solar irradiation and low wind speeds establishing heatwaves also enhance urban heat island intensities [De Ridder et al., 2016]. The terms CPM_M - and CPM_TD - denote the additional heat-stress increase under climate change resulting from the higher temperatures - especially during heatwaves - in the cities than in the rural areas. Such an excessive heat-stress increase originates from the nonlinear response of the heat-stress (indicator) to increasing temperatures (taking both the number and intensity of heatwave days into account) occurring at the global and synoptic scale.

Finally, a further excess in heat stress results from the local land-use change by urban expansion (CPM_LUC) for the three urban categories. It mostly affects the peri-urban areas where the urban expansion typically takes place, yet it also affects the city centers. Here, an excess accumulation takes place in the peri-urban areas around the city centers; At night, the air in the direction of the urban centers accumulates more heat (or is cooled less) due to the increasing amount of heat stored in the cities' periphery. This eventually leads to a greater UHI intensity in the centers. While the additional effect from urban expansion seems small, the overall heat-stress increase is found to be twice as large in urban areas compared to the rural areas. This is not contradicting: in the former, the effect of urban expansion does not reflect (yet accounts for) the effect of existing urbanization. In the latter, the heat-stress increase also considers the effect of existing urbanization. Furthermore, additional future urban heat-stress increase established by local land-use change averaged for the three urban categories may seem small compared to that established by the global emissions on the scale of the study domain. Still, this further exacerbation may have important consequences for the city centers in the median and worst-case emission scenarios. Moreover, it should be noted that new emerging urban areas experience strong impacts as their future heat stress becomes more similar to the existing urban areas (compare lower panels with upper panels of Figure 2), particularly the new urban sprawl around Brussels and Antwerp in the center of the domain.

\section{Discussion}

Our results are consistent with previous heat-stress assessments which also found a profound heat-stress increase in response to greenhouse-gas induced climate change [Fischer and Schär, 2010; Meehl and Tebaldi, 2004; Huth et al., 2000], and an amplification by the expanding urban land forms [Argüeso et al., 2015; Fischer et al., 2012]. They support the view that there will be a strong increase in the risk of heatwave-related problems, especially for citizens' mortality because of more extreme future heatwaves [Mora et al., 2017; Wilby, 2008]. However, the new framework, that combines climate models acting on the different scales, offers novel insights on the relation between heatwave-related problems, urbanization and climate change, and are summarized below:

- By explicitly resolving the inter-urban heterogeneity, the urban CPM reveals the propagation of heat-stress increase under climate change towards the scales of the cities. It also indicates its dependency to the city size and imperviousness, and to other local environmental aspects such as distance from the coastline, soil texture and orography. As such, local hot spots of heat stress are identified, and particularly the role of urban heat islands and their concurrence with heatwaves. Moreover, our modelling approach reveals the additional role of local land-use change indicating that urban expansion results in a further amplification of heat-stress increase under climate change.

- The incorporation of the ensemble information from the GCMs allows us to quantify the climatic drivers of heat stress at the global and synoptic scale, especially the role of the trends in both averaged and extreme temperature.

- The combination of the ensemble global emission scenarios and local land-use change scenarios enables a comprehensive quantification of the different heat-stress drivers under climate change at the global to the local scale. This includes the characteriza- 
tion of the uncertainty ranging from a best-case to a worst-case global emission scenario.

While the urban heat-stress drivers and the underlying mechanisms are explained for a specific region, their implications are relevant for other regions around the world. Particularly, the majority of cities are susceptible to global warming and UHIs, which could lead to comparable climate drivers of heat stress as those found for the current study area. Still, this needs to be verified with additional climate assessments.

Our study further exemplifies that the model framework - especially urban CPM holds great promise for urban-climate assessment with respect to other regions and other risks related to climate change. Especially, one should consider the (sub-)tropic developing regions for which urban expansion and population growth are expected to be much larger than in mid-latitude developed regions [United Nations, 2014; Seto et al., 2012]. Besides the heat-stress assessment, the framework may also serve as a basis for assessing other weather extremes and risks under climate change propagating to the city scales, especially urbaninduced precipitation [eg., Han et al., 2014; Jin et al., 2015] and its consequences on urban flooding and (vector-borne) diseases. Still, limitations of the current assessment need to be kept in mind with respect to the heat-stress quantification (Text S8.1), urban-climate observations, modelling and projections (Text S8.2) and land-use modelling (Text S8.3). Especially, one should keep in mind that our study employs projected temperature changes derived from ensemble GCM simulations, for which changes in the local (city-scale) feedbacks and other meteorological variables for heat-stress quantification are neglected. The challenges need to be tackled with new research directions and modelling techniques, which are discussed further in the supporting Text S8 [Mora et al., 2017; Leutwyler et al., 2016; Xu et al., 2016; Buzan et al., 2015; Hondula et al., 2014; Wouters et al., 2013; Bohnenstengel et al., 2011; Barnett et al., 2010; Matzarakis et al., 2010; Epstein and Moran, 2006].

\section{Implications for policy}

Our study highlights that one requires combined measures of heat-resistance and sustainability against global warming, especially in urban areas. Especialy, the quantification of the different heat-stress drivers under climate change demonstrate that adaptation and mitigation strategies should come together:

- From a global perspective, mitigating the global heat-stress drivers requires drastic reduction of greenhouse-gas emissions in systems for energy, housing, industry, food, movables and mobility.

- From a regional perspective, one should prioritize those strategies that also mitigate the local drivers by reducing the urban heat island effect. Particularly, the transformation of the urban areas into compact cities with a low-carbon infrastructure [Creutzig et al., 2016; Seto et al., 2010] (reducing the motorized traffic, building-energy consumption and petrified footprint) will not only alleviate the heat-stress increase from greenhouse gas emissions, but also that from urban expansion and anthropogenic heating.

- From a local perspective, the future heat-stress drivers highlight the need for targeted strategies in spatial, organizational, behavioral and technological climate adaptation [Hanna and Tait, 2015; Revi et al., 2014; Georgescu et al., 2014] that enhance the cities' resilience to a changing climate and attractiveness. Such adaptation includes the integration of green open spaces and waterways in urban spatial planning, watersensitive urban design and building adaptation [Demuzere et al., 2014; Coutts et al., 2012; Willems et al., 2012].

Interdisciplinary research needs to pursue optimal pathways for future urbanization, for which heat-reducing strategies apply to the multiple scales of climate change on the one hand and 
of policy-making on the other hand. It is clear from our study that urban convection-permitting models should serve as a key tool.

\section{Acknowledgments}

We acknowledge the World Climate Research Programme's Working Group on Coupled Modelling, which is responsible for CMIP, and we thank the climate modelling groups (listed in Table S3) for producing and making available their model output. For CMIP the U.S. Department of Energy's Program for Climate Model Diagnosis and Intercomparison provides coordinating support and led development of software infrastructure in partnership with the Global Organization for Earth System Science Portals. We also acknowledge the CLMcommunity for the developing COSMO-CLM model, and for providing the model code and the CORDEX-Europe boundary conditions. In addition, we are grateful to the World Climate Research Programme (WRCP) for initiating and coordinating the CORDEX-Europe initiative, ECMWF for providing access to the ERA-Interim dataset, the EU-FP6 project ENSEMBLES (http://ensembles-eu.metoffice.com) and the data providers in the ECA\&D project (http://www . ecad.eu) for making the E-OBS dataset publicly available. We particularly thank Dr. Bino Maiheu for coordinating the urban-climate observations for Antwerp anf Ghent, and for providing the data. The work described in this paper has received funding from the Belgian Science Policy Office through its Science for a Sustainable Development Programme under Contracts SD/CS/041/MACCBET and BR/143/A2/CORDEX.be. It has also received funding from the Flemish Government through a contract as an FWO (Fund for Scientific Research) post-doctoral position, and from the EU-H2020 programme through the 'BRIGAID - BRIdges the GAp for Innovations in Disaster resilience' project. The computational resources and services used for the downscaling were provided by the Hercules Foundation and the Flemish Government (department Economics, Sciences and Innovation EWI). We are thankful to the revievers for their constructive comments, which have considerably improved the quality of the manuscript. The climate data can be requested through the CORDEX.be project portal (http://www . euro-cordex.be).

\section{References}

Acosta-Michlik, L., H. B. de Frahan, H. Brunke, K. Hansen, G. Engelen, I. Uljee, A. Van Herzele, M. Rounsevell, and R. White (2011), Multiscalar and Multiagent Modelling Framework for Assessing Sustainable Futures in a Globalised Environment (MULTIMODE), Final Report, Tech. rep., Belgian Science Policy, Research Programme Science for a Sustainable Development, Brussels.

Ahlström, A., G. Schurgers, A. Arneth, and B. Smith (2012), Robustness and uncertainty in terrestrial ecosystem carbon response to CMIP5 climate change projections, Environmental Research Letters, 7(4), 044,008, doi:10.1088/1748-9326/7/4/044008.

Akkermans, T., W. Thiery, and N. P. M. Van Lipzig (2014), The Regional Climate Impact of a Realistic Future Deforestation Scenario in the Congo Basin, Journal of Climate, 27(7), 2714-2734, doi:10.1175/JCLI-D-13-00361.1.

Argüeso, D., J. P. Evans, A. J. Pitman, and A. Di Luca (2015), Effects of city expansion on heat stress under climate change conditions., PloS one, 10(2), e0117,066, doi:10.1371/ journal.pone.0117066.

Barnett, A., S. Tong, and A. Clements (2010), What measure of temperature is the best predictor of mortality?, Environmental Research, 110(6), 604-611, doi:10.1016/j.envres. 2010.05.006.

Barriopedro, D., E. M. Fischer, J. Luterbacher, R. M. Trigo, and R. García-Herrera (2011), The Hot Summer of 2010: Redrawing the Temperature Record Map of Europe, Science, 332(6026).

Beniston, M., D. B. Stephenson, O. B. Christensen, C. A. T. Ferro, C. Frei, S. Goyette, K. Halsnaes, T. Holt, K. Jylhä, B. Koffi, J. Palutikof, R. Schöll, T. Semmler, and K. Woth (2007), Future extreme events in European climate: an exploration of regional climate 
model projections, Climatic Change, 81(S1), 71-95, doi:10.1007/s10584-006-9226-z.

Bohnenstengel, S. I., S. Evans, P. a. Clark, and S. Belcher (2011), Simulations of the London urban heat island, Q.J.R. Meteorol. Soc., 137(659), 1625-1640, doi:10.1002/qj.855.

Brisson, E., M. Demuzere, and N. P. van Lipzig (2016a), Modelling strategies for performing convection-permitting climate simulations, Meteorologische Zeitschrift, 25(2), 149-163, doi:10.1127/metz/2015/0598.

Brisson, E., K. Van Weverberg, M. Demuzere, A. Devis, S. Saeed, M. Stengel, and N. P. M. van Lipzig (2016b), How well can a convection-permitting climate model reproduce decadal statistics of precipitation, temperature and cloud characteristics?, Climate Dynamics, doi:10.1007/s00382-016-3012-z.

Brouwers, J., B. Peeters, M. Van Steertegem, N. van Lipzig, H. Wouters, J. Beullens, M. Demuzere, P. Willems, K. De Ridder, B. Maiheu, R. De Troch, P. Termonia, T. Vansteenkiste, M. Craninx, W. Maetens, W. Defloor, and K. Cauwenberghs (2015), MIRA Climate Report 2015, about observed and future climate changes in Flanders and Belgium, Tech. rep., Flanders Environment Agency in collaboration with KU Leuven, VITO and RMI, Aalst, Belgium.

Buzan, J. R., K. Oleson, and M. Huber (2015), Implementation and comparison of a suite of heat stress metrics within the Community Land Model version 4.5, Geoscientific Model Development, 8(2), 151-170, doi:10.5194/gmd-8-151-2015.

Buzzi, M. (2008), Challenges in operational numerical weather prediction at high resolution in complex terrain, Ph.D. thesis, Zürich, doi:10.3929/ethz-a-005698833.

Coutts, A. M., N. J. Tapper, J. Beringer, M. Loughnan, and M. Demuzere (2012), Watering our cities: The capacity for Water Sensitive Urban Design to support urban cooling and improve human thermal comfort in the Australian context, Progress in Physical Geography, 37(1), 2-28, doi:10.1177/0309133312461032.

Cox, B., A. Gasparrini, B. Catry, A. Delcloo, E. Bijnens, J. Vangronsveld, and T. S. Nawrot (2016), Mortality related to cold and heat. What do we learn from dairy cattle?, Environmental Research, 149, 231-238, doi:10.1016/j.envres.2016.05.018.

Creutzig, F., P. Agoston, J. C. Minx, J. G. Canadell, R. M. Andrew, C. L. Quéré, G. P. Peters, A. Sharifi, Y. Yamagata, and S. Dhakal (2016), Urban infrastructure choices structure climate solutions, Nature Climate Change, 6(12), 1054-1056, doi:10.1038/nclimate3169.

Davin, E. L., S. I. Seneviratne, P. Ciais, A. Olioso, and T. Wang (2014), Preferential cooling of hot extremes from cropland albedo management., Proceedings of the National Academy of Sciences of the United States of America, 111(27), 9757-9761, doi:10.1073/ pnas.1317323111.

Davin, E. L., E. Maisonnave, and S. I. Seneviratne (2016), Is land surface processes representation a possible weak link in current Regional Climate Models?, Environmental Research Letters, 11(7), 074,027, doi:10.1088/1748-9326/11/7/074027.

Davy, R., and I. Esau (2014), Global climate models' bias in surface temperature trends and variability, Environmental Research Letters, 9(11), 114,024, doi:10.1088/1748-9326/9/11/ 114024.

De Ridder, K., D. Lauwaet, and B. Maiheu (2015), UrbClim - A fast urban boundary layer climate model, Urban Climate, 12, 21-48, doi:10.1016/j.uclim.2015.01.001.

De Ridder, K., B. Maiheu, D. Lauwaet, I. Daglis, I. Keramitsoglou, K. Kourtidis, P. Manunta, and M. Paganini (2016), Urban Heat Island Intensification during Hot Spells The Case of Paris during the Summer of 2003, Urban Science, 1(1), 3, doi:10.3390/ urbansci1010003.

Demuzere, M., A. Coutts, M. Göhler, A. Broadbent, H. Wouters, N. van Lipzig, and L. Gebert (2014), The implementation of biofiltration systems, rainwater tanks and urban irrigation in a single-layer urban canopy model, Urban Climate, 10, 148-170, doi: 10.1016/j.uclim.2014.10.012.

Demuzere, M., S. Harshan, L. Järvi, M. Roth, C. Grimmond, V. Masson, K. Oleson, E. Velasco, and H. Wouters (2017), Impact of urban canopy models and external parameters on the modelled urban energy balance in a tropical city, Quarterly Journal of the Royal Mete- 
orological Society, doi:10.1002/qj.3028.

Díaz, J., R. Carmona, I. Mirón, C. Ortiz, and C. Linares (2015), Comparison of the effects of extreme temperatures on daily mortality in Madrid (Spain), by age group: The need for a cold wave prevention plan, Environmental Research, 143, 186-191, doi:10.1016/j.envres. 2015.10.018.

Diffenbaugh, N. S., and F. Giorgi (2012), Climate change hotspots in the CMIP5 global climate model ensemble., Climatic change, 114(3-4), 813-822, doi:10.1007/ s10584-012-0570-x.

Dimitrova, R., Z. Silver, T. Zsedrovits, C. M. Hocut, L. S. Leo, S. Di Sabatino, and H. J. S. Fernando (2016), Assessment of Planetary Boundary-Layer Schemes in the Weather Research and Forecasting Mesoscale Model Using MATERHORN Field Data, BoundaryLayer Meteorology, 159(3), 589-609, doi:10.1007/s10546-015-0095-8.

Doms, G., J. Förstner, E. Heise, H.-J. Herzog, M. Raschendorfer, T. Reinhardt, T. Ritter, R. Schrodin, J.-P. Schulz, and G. Vogel (2011), A description of the nonhydrostatic regional COSMO model. Part II: Physical parameterization, 153 pp., Deutscher Wetterdienst.

Donat, M. G., and L. V. Alexander (2012), The shifting probability distribution of global daytime and night-time temperatures, Geophysical Research Letters, 39(14), L14,707, doi: 10.1029/2012GL052459.

Epstein, Y., and D. S. Moran (2006), Thermal comfort and the heat stress indices., Industrial health, 44(3), 388-98.

Estrada, F., W. J. W. Botzen, and R. S. J. Tol (2017), A global economic assessment of city policies to reduce climate change impacts, Nature Climate Change, 7(6), 403-406, doi: 10.1038/nclimate3301.

Fischer, E. M., and C. Schär (2010), Consistent geographical patterns of changes in highimpact European heatwaves, Nature Geoscience, 3(6), 398-403, doi:10.1038/ngeo866.

Fischer, E. M., K. W. Oleson, and D. M. Lawrence (2012), Contrasting urban and rural heat stress responses to climate change, Geophysical Research Letters, 39(3), L03,705, doi: 10.1029/2011GL050576.

Fosser, G., S. Khodayar, and P. Berg (2017), Climate change in the next 30 years: What can a convection-permitting model tell us that we did not already know?, Climate Dynamics, 48(5-6), 1987-2003, doi:10.1007/s00382-016-3186-4.

Gabriel, K. M. a., and W. R. Endlicher (2011), Urban and rural mortality rates during heat waves in Berlin and Brandenburg, Germany., Environmental pollution (Barking, Essex : 1987), 159(8-9), 2044-50, doi:10.1016/j.envpol.2011.01.016.

Georgescu, M., P. E. Morefield, B. G. Bierwagen, and C. P. Weaver (2014), Urban adaptation can roll back warming of emerging megapolitan regions., Proceedings of the National Academy of Sciences of the United States of America, 111(8), 2909-14, doi:10.1073/pnas. 1322280111 .

Grasselt, R. (2008), Validation of TERRA-ML with discharge measurements, Meteorologische Zeitschrift, 17(6), 763-773, doi:10.1127/0941-2948/2008/0334.

Green, H. K., N. Andrews, B. Armstrong, G. Bickler, and R. Pebody (2016), Mortality during the 2013 heatwave in England âĂŞ How did it compare to previous heatwaves? A retrospective observational study, Environmental Research, 147, 343-349, doi: 10.1016/j.envres.2016.02.028.

Grimm, N. B., S. H. Faeth, N. E. Golubiewski, C. L. Redman, J. Wu, X. Bai, and J. M. Briggs (2008), Global change and the ecology of cities., Science, 319(5864), 756-760, doi:10.1126/science.1150195.

Grossman-Clarke, S., S. Schubert, and D. Fenner (2016), Urban effects on summertime air temperature in Germany under climate change, International Journal of Climatology, doi: 10.1002/joc.4748.

Hamdi, R., F. Duchêne, J. Berckmans, A. Delcloo, C. Vanpoucke, and P. Termonia (2016), Evolution of urban heat wave intensity for the Brussels Capital Region in the ARPEGEClimat A1B scenario, Urban Climate, 17, 176-195, doi:10.1016/j.uclim.2016.08.001. 
Han, J.-Y., J.-J. Baik, and H. Lee (2014), Urban impacts on precipitation, Asia-Pacific Journal of Atmospheric Sciences, 50(1), 17-30, doi:10.1007/s13143-014-0016-7.

Hanna, E. G., and P. W. Tait (2015), Limitations to Thermoregulation and Acclimatization Challenge Human Adaptation to Global Warming., International journal of environmental research and public health, 12(7), 8034-8074, doi:10.3390/ijerph120708034.

Haylock, M. R., N. Hofstra, A. M. G. Klein Tank, E. J. Klok, P. D. Jones, and M. New (2008), A European daily high-resolution gridded data set of surface temperature and precipitation for 1950âĂŞ2006, Journal of Geophysical Research, 113(D20), D20,119, doi:10.1029/2008JD010201.

Heaviside, C., S. Vardoulakis, and X.-M. Cai (2016), Attribution of mortality to the urban heat island during heatwaves in the West Midlands, UK, Environmental Health, 15(1), S27, doi:10.1186/s12940-016-0100-9.

Hoag, H. (2015), How cities can beat the heat, Nature, 524(7566), 402-404, doi:10.1038/ 524402a.

Hondula, D. M., M. Georgescu, and R. C. Balling (2014), Challenges associated with projecting urbanization-induced heat-related mortality, Science of The Total Environment, 490, 538-544, doi:10.1016/j.scitotenv.2014.04.130.

Horton, D. E., N. C. Johnson, D. Singh, D. L. Swain, B. Rajaratnam, and N. S. Diffenbaugh (2015), Contribution of changes in atmospheric circulation patterns to extreme temperature trends., Nature, 522(7557), 465-469, doi:10.1038/nature14550.

Huang, C., A. G. Barnett, X. Wang, and S. Tong (2012), The impact of temperature on years of life lost in Brisbane, Australia, Nature Climate Change, 2(4), 265-270, doi:10.1038/ nclimate1369.

Huth, R., J. Kyselý, and L. Pokorná (2000), A GCM Simulation of Heat Waves, Dry Spells, and Their Relationships to Circulation, Climatic Change, 46(1/2), 29-60, doi:10.1023/A: 1005633925903.

Iñiguez, C., P. Schifano, F. Asta, P. Michelozzi, A. Vicedo-Cabrera, and F. Ballester (2016), Temperature in summer and children's hospitalizations in two Mediterranean cities, Environmental Research, 150, 236-244, doi:10.1016/j.envres.2016.06.007.

Jacob, D., L. Bärring, O. B. Christensen, J. H. Christensen, M. de Castro, M. Déqué, F. Giorgi, S. Hagemann, M. Hirschi, R. Jones, E. Kjellström, G. Lenderink, B. Rockel, E. Sánchez, C. Schär, S. I. Seneviratne, S. Somot, A. van Ulden, and B. van den Hurk (2007), An inter-comparison of regional climate models for Europe: model performance in present-day climate, Climatic Change, 81(S1), 31-52, doi:10.1007/s10584-006-9213-4.

Jacob, D., J. Petersen, B. Eggert, A. Alias, O. B. Christensen, L. M. Bouwer, A. Braun, A. Colette, M. Déqué, G. Georgievski, E. Georgopoulou, A. Gobiet, L. Menut, G. Nikulin, A. Haensler, N. Hempelmann, C. Jones, K. Keuler, S. Kovats, N. Kröner, S. Kotlarski, A. Kriegsmann, E. Martin, E. van Meijgaard, C. Moseley, S. Pfeifer, S. Preuschmann, C. Radermacher, K. Radtke, D. Rechid, M. Rounsevell, P. Samuelsson, S. Somot, J.-F. Soussana, C. Teichmann, R. Valentini, R. Vautard, B. Weber, and P. Yiou (2013), EUROCORDEX: new high-resolution climate change projections for European impact research, Regional Environmental Change, 14(2), 563-578, doi:10.1007/s10113-013-0499-2.

Jänicke, B., F. Meier, D. Fenner, U. Fehrenbach, A. Holtmann, and D. Scherer (2016), Urban-rural differences in near-surface air temperature as resolved by the Central Europe Refined analysis (CER): sensitivity to planetary boundary layer schemes and urban canopy models, International Journal of Climatology, doi:10.1002/joc.4835.

Jin, M., Y. Li, and D. Su (2015), Urban-Induced Mechanisms for an Extreme Rainfall Event in Beijing China: A Satellite Perspective, Climate, 3(1), 193-209, doi:10.3390/ cli3010193.

Kalnay, E., and M. Cai (2003), Impact of urbanization and land-use change on climate, $\mathrm{Na}$ ture, 423(6939), 528-531, doi:10.1038/nature01675.

Kendon, E. J., N. Ban, N. M. Roberts, H. J. Fowler, M. J. Roberts, S. C. Chan, J. P. Evans, G. Fosser, J. M. Wilkinson, E. J. Kendon, N. Ban, N. M. Roberts, H. J. Fowler, M. J. Roberts, S. C. Chan, J. P. Evans, G. Fosser, and J. M. Wilkinson (2017), Do Convection- 
Permitting Regional Climate Models Improve Projections of Future Precipitation Change?, Bulletin of the American Meteorological Society, 98(1), 79-93, doi:10.1175/ BAMS-D-15-0004.1.

Kotlarski, S., K. Keuler, O. B. Christensen, A. Colette, M. Déqué, A. Gobiet, K. Goergen, D. Jacob, D. Lüthi, E. van Meijgaard, G. Nikulin, C. Schär, C. Teichmann, R. Vautard, K. Warrach-Sagi, and V. Wulfmeyer (2014), Regional climate modeling on European scales: a joint standard evaluation of the EURO-CORDEX RCM ensemble, Geoscientific Model Development, 7(4), 1297-1333, doi:10.5194/gmd-7-1297-2014.

Laaidi, K., A. Zeghnoun, B. Dousset, P. Bretin, and S. Vandentorren (2011), The Impact of Heat Islands on Mortality in Paris during the August 2003 Heatwave, Environ. Health Perspect., 120(2), 254-259, doi:10.1289/ehp.1103532.

Leutwyler, D., O. Fuhrer, X. Lapillonne, D. Lüthi, and C. Schär (2016), Towards Europeanscale convection-resolving climate simulations with GPUs: a study with COSMO 4.19, Geoscientific Model Development, 9(9), 3393-3412, doi:10.5194/GMD-9-3393-2016.

Li, D., and E. Bou-Zeid (2013), Synergistic Interactions between Urban Heat Islands and Heat Waves: the Impact in Cities is Larger than the Sum of its Parts, Journal of Applied Meteorology and Climatology, p. 130528133440007, doi:10.1175/JAMC-D-13-02.1.

Linares, C., D. Culqui, R. Carmona, C. Ortiz, and J. Díaz (2017), Short-term association between environmental factors and hospital admissions due to dementia in Madrid, Environmental Research, 152, 214-220, doi:10.1016/j.envres.2016.10.020.

Matzarakis, A., F. Rutz, and H. Mayer (2010), Modelling radiation fluxes in simple and complex environments: basics of the RayMan model, International Journal of Biometeorology, 54(2), 131-139, doi:10.1007/s00484-009-0261-0.

Maucha, G., G. Büttner, and B. Kosztra (2010), European validation of GMES FTS Soil Sealing Enhancement Data, Final Draft, Tech. rep., European Environmental Agency.

Mazdiyasni, O., A. AghaKouchak, S. J. Davis, S. Madadgar, A. Mehran, E. Ragno, M. Sadegh, A. Sengupta, S. Ghosh, C. T. Dhanya, and M. Niknejad (2017), Increasing probability of mortality during Indian heat waves, Science Advances, 3(6).

Meehl, G. A., and C. Tebaldi (2004), More Intense, More Frequent, and Longer Lasting Heat Waves in the 21st Century, Science, 305(5686).

Mitchell, D., C. Heaviside, S. Vardoulakis, C. Huntingford, G. Masato, B. P Guillod, P. Frumhoff, A. Bowery, D. Wallom, and M. Allen (2016), Attributing human mortality during extreme heat waves to anthropogenic climate change, Environmental Research Letters, 11(7), 074,006, doi:10.1088/1748-9326/11/7/074006.

Mora, C., Benedicte Dousset, I. R. Caldwell, F. E. Powell, R. C. Geronimo, C. Bielecki, C. W. W. Counsell, B. S. Dietrich, E. T. Johnston, L. V. Louis, M. P. Lucas, M. M. McKenzie, A. G. Shea, H. Tseng, T. W. Giambelluca, L. R. Leon, E. Hawkins, and C. Trauernicht (2017), Global risk of deadly heat, Nature Climate Change, doi:10.1038/ nclimate 3322 .

Moss, R., N. Nakicenovic, and B. O'Neill (2008), Towards New Scenarios for Analysis of Emissions, Climate Change, Impacts, and Response Strategies, IPCC, Geneva.

Prein, A. F., A. Gobiet, M. Suklitsch, H. Truhetz, N. K. Awan, K. Keuler, and G. Georgievski (2013), Added value of convection permitting seasonal simulations, Climate Dynamics, 41(9-10), 2655-2677, doi:10.1007/s00382-013-1744-6.

Prein, A. F., W. Langhans, G. Fosser, A. Ferrone, N. Ban, K. Goergen, M. Keller, M. Tölle, O. Gutjahr, F. Feser, E. Brisson, S. Kollet, J. Schmidli, N. P. M. van Lipzig, and R. Leung (2015), A review on regional convection-permitting climate modeling: Demonstrations, prospects, and challenges, Reviews of Geophysics, 53(2), 323-361, doi:10.1002/ 2014RG000475.

Revi, A., D. E. Satterthwaite, F. Aragón-Durand, J. Corfee-Morlot, R. B. R. Kiunsi, M. Pelling, D. C. Roberts, and W. Solecki (2014), Urban areas, in Climate Change 2014: Impacts, Adaptation, and Vulnerability. Part A: Global and Sectoral Aspects. Contribution of Working Group II to the Fifth Assessment Report of the Intergovernmental Panel of Climate Change, edited by C. B. Field, V. R. Barros, D. J. Dokken, K. J. Mach, M. D. 
Mastrandrea, T. E. Bilir, M. Chatterjee, K. L. Ebi, Y. O. Estrada, R. C. Genova, B. Girma, E. S. Kissel, A. N. Levy, S. MacCracken, P. R. Mastrandrea, and L. L. White, pp. 535612, Cambridge University Press, Cambridge, United Kingdom and New York, NY, USA.

Rockel, B., A. Will, and A. Hense (2008), The Regional Climate Model COSMO-CLM (CCLM), Meteorologische Zeitschrift, 17(4), 347-348.

Schär, C., P. L. Vidale, D. Lüthi, C. Frei, C. Häberli, M. A. Liniger, and C. Appenzeller (2004), The role of increasing temperature variability in European summer heatwaves., Nature, 427(6972), 332-6, doi:10.1038/nature02300.

Schulz, J.-P., G. Vogel, C. Becker, S. Kothe, U. Rummel, and B. Ahrens (2016), Evaluation of the ground heat flux simulated by a multi-layer land surface scheme using high-quality observations at grass land and bare soil, Meteorologische Zeitschrift, doi:10.1127/metz/ 2016/0537.

Seneviratne, S. I., D. Lüthi, M. Litschi, and C. Schär (2006), Land-atmosphere coupling and climate change in Europe., Nature, 443(7108), 205-209, doi:10.1038/nature05095.

Seto, K. C., R. Sánchez-Rodríguez, and M. Fragkias (2010), The New Geography of Contemporary Urbanization and the Environment, Annual Reviews, 35, 167-194, doi: 10.1146/annurev-environ-100809-125336.

Seto, K. C., B. Güneralp, and L. R. Hutyra (2012), Global forecasts of urban expansion to 2030 and direct impacts on biodiversity and carbon pools., Proceedings of the National Academy of Sciences of the United States of America, 109(40), 16,083-16,088, doi:10. 1073/pnas.1211658109.

Smiatek, G., B. Rockel, and U. Schättler (2008), Time invariant data preprocessor for the climate version of the COSMO model (COSMO-CLM), Meteorologische Zeitschrift, 17(4), 395-405, doi:10.1127/0941-2948/2008/0302.

Stein, U., and P. Alpert (1993), Factor separation in numerical simulations, Journal of the Atmospheric Sciences, 50, 2107-2115.

Steppeler, J., G. Doms, U. Schättler, H. W. Bitzer, A. Gassmann, U. Damrath, and G. Gregoric (2003), Meso-gamma scale forecasts using the nonhydrostatic model LM, Meteorology and Atmospheric Physics, 82(1-4), 75-96, doi:10.1007/s00703-001-0592-9.

Tabari, H., M. T. Taye, and P. Willems (2015), Water availability change in central Belgium for the late 21st century, Global and Planetary Change, 131, 115-123, doi:10.1016/j. gloplacha.2015.05.012.

Taylor, K. E., R. J. Stouffer, and G. A. Meehl (2012), An Overview of CMIP5 and the Experiment Design, Bulletin of the American Meteorological Society, 93(4), 485-498, doi: 10.1175/BAMS-D-11-00094.1.

The World Bank (2017), http://data.worldbank.org/indicator/ (access date: 2017/03/30).

Thiery, W., E. L. Davin, S. I. Seneviratne, K. Bedka, S. Lhermitte, and N. P. M. van Lipzig (2016), Hazardous thunderstorm intensification over Lake Victoria, Nature Communications, 7, 12,786, doi:10.1038/ncomms 12786.

Tong, S., G. FitzGerald, X.-Y. Wang, P. Aitken, V. Tippett, D. Chen, X. Wang, and Y. Guo (2015), Exploration of the health risk-based definition for heatwave: A multi-city study, Environmental Research, 142, 696-702, doi:10.1016/j.envres.2015.09.009.

Trusilova, K., S. Schubert, H. Wouters, B. Früh, S. Grossman-Clarke, M. Demuzere, and P. Becker (2016), The urban land use in the COSMO-CLM model: a comparison of three parameterizations for Berlin, Meteorologische Zeitschrift, 25(2), 231-244, doi:10.1127/ metz/2015/0587.

United Nations (2014), World Urbanization Prospects: The 2014 Revision, Tech. rep., United Nations, Department of Economic and Social Affairs, Population Division, ST/ESA/SER.A/366.

Van Weverberg, K., K. De Ridder, and A. Van Rompaey (2008), Modeling the Contribution of the Brussels Heat Island to a Long Temperature Time Series, J. Appl. Meteor. Climatol., 47, 976-990, doi:10.1175/2007JAMC1482.1.

Vanden Broucke, S., S. Luyssaert, E. L. Davin, I. Janssens, and N. van Lipzig (2015), New insights in the capability of climate models to simulate the impact of LUC based on tem- 
perature decomposition of paired site observations, Journal of Geophysical Research: Atmospheres, 120(11), 5417-5436, doi:10.1002/2015JD023095.

Vautard, R., A. Gobiet, D. Jacob, M. Belda, A. Colette, M. Déqué, J. Fernández, M. GarcíaDíez, K. Goergen, I. Güttler, T. Halenka, T. Karacostas, E. Katragkou, K. Keuler, S. Kotlarski, S. Mayer, E. van Meijgaard, G. Nikulin, M. Patarčić, J. Scinocca, S. Sobolowski, M. Suklitsch, C. Teichmann, K. Warrach-Sagi, V. Wulfmeyer, and P. Yiou (2013), The simulation of European heat waves from an ensemble of regional climate models within the EURO-CORDEX project, Climate Dynamics, 41(9-10), 2555-2575, doi:10.1007/ s00382-013-1714-z.

Vogel, M. M., R. Orth, F. Cheruy, S. Hagemann, R. Lorenz, B. J. J. M. Hurk, and S. I. Seneviratne (2017), Regional amplification of projected changes in extreme temperatures strongly controlled by soil moistureâĂ ̌̌temperature feedbacks, Geophysical Research Letters, 44(3), 1511-1519, doi:10.1002/2016GL071235.

Watts, N., W. N. Adger, P. Agnolucci, J. Blackstock, P. Byass, W. Cai, S. Chaytor, T. Colbourn, M. Collins, A. Cooper, P. M. Cox, J. Depledge, P. Drummond, P. Ekins, V. Galaz, D. Grace, H. Graham, M. Grubb, A. Haines, I. Hamilton, A. Hunter, X. Jiang, M. Li, I. Kelman, L. Liang, M. Lott, R. Lowe, Y. Luo, G. Mace, M. Maslin, M. Nilsson, T. Oreszczyn, S. Pye, T. Quinn, M. Svensdotter, S. Venevsky, K. Warner, B. Xu, J. Yang, Y. Yin, C. Yu, Q. Zhang, P. Gong, H. Montgomery, and A. Costello (2015), Health and climate change: policy responses to protect public health, The Lancet, 386(10006), 18611914, doi:10.1016/S0140-6736(15)60854-6.

White, R., and G. Engelen (2000), High-resolution integrated modelling of the spatial dynamics of urban and regional systems, Computers, Environment and Urban Systems, 24(5), 383-400, doi:10.1016/S0198-9715(00)00012-0.

Wilby, R. L. (2008), Constructing climate change scenarios of urban heat island intensity and air quality, Environment and Planning B: Planning and Design, 35(5), 902-919, doi: 10.1068/b33066t.

Willems, P., and M. Vrac (2011), Statistical precipitation downscaling for small-scale hydrological impact investigations of climate change, Journal of Hydrology, 402(3), 193-205, doi:10.1016/j.jhydrol.2011.02.030.

Willems, P., J. Olsson, K. Arnbjerg-Nielsen, S. Beecham, A. Pathirana, I. B. Gregersen, and H. Madsen (2012), Impacts of climate change on rainfall extremes and urban drainage systems, 238 pp., The International Water Association, London.

WMO (2008), Guide to Meteorological Instruments and Methods of Observation, seventh ed ed., 681 pp., Geneva.

WMO (2014), Atlas of Mortality and Economic Losses from Weather, Climate and Water Extremes 1970-2012, Tech. rep., World Meterological Organization, Geneva.

Wouters, H., K. De Ridder, M. Demuzere, D. Lauwaet, and N. P. M. van Lipzig (2013), The diurnal evolution of the urban heat island of Paris: a model-based case study during Summer 2006, Atmospheric Chemistry and Physics, 13(17), 8525-8541, doi:10.5194/ acp-13-8525-2013.

Wouters, H., M. Demuzere, K. De Ridder, and N. P. van Lipzig (2015), The impact of impervious water-storage parametrization on urban climate modelling, Urban Climate, 11, 24-50, doi:10.1016/j.uclim.2014.11.005.

Wouters, H., M. Demuzere, U. Blahak, K. Fortuniak, B. Maiheu, J. Camps, D. Tielemans, and N. P. M. van Lipzig (2016), The efficient urban canopy dependency parametrization (SURY) v1.0 for atmospheric modelling: description and application with the COSMOCLM model for a Belgian summer, Geoscientific Model Development, 9(9), 3027-3054, doi:10.5194/gmd-9-3027-2016.

Xu, Z., G. FitzGerald, Y. Guo, B. Jalaludin, and S. Tong (2016), Impact of heatwave on mortality under different heatwave definitions: A systematic review and meta-analysis, Environment International, 89, 193-203, doi:10.1016/j.envint.2016.02.007.

Zander, K. K., W. J. W. Botzen, E. Oppermann, T. Kjellstrom, and S. T. Garnett (2015), Heat stress causes substantial labour productivity loss in Australia, Nature Climate Change, 
5(7), 647-651, doi:10.1038/nclimate2623.

Zhou, B., D. Rybski, and J. P. Kropp (2013), On the statistics of urban heat island intensity, Geophysical Research Letters, 40(20), 5486-5491, doi:10.1002/2013GL057320. 